\title{
Controversies in the Management of Respiratory Distress Syndrome in Premature Neonates
}

\section{Alan M Fujii*}

Department of Pediatrics, Boston Medical Center and Boston University School of Medicine, Boston, USA

Current practices have lowered morbidity and mortality in premature infants over the past two decades. This improvement in outcomes is associated with regionalization of antenatal obstetrical management of potential preterm deliveries by referrals to centers with high-risk obstetricians and Neonatal Intensive Care Units (NICUs), timely administration of antenatal steroids before delivery [1-3] and improving neonatal intensive care strategies. Nonetheless, Respiratory Distress Syndrome (RDS), due to surfactant deficiency, continues to be a major cause of morbidity and mortality in the United States. Neonatology is a relatively new subspecialty in which clinical strategies frequently are not supported by the robust evidence based data found in other specialties. Thus, NICU strategies tend to change rapidly and it is difficult for the clinician to keep abreast of the new information. This Special Edition of the Journal of Pulmonary and Respiratory Medicine is created to provide the general pediatrician and practicing clinical neonatologist with an update of the state on the art care of RDS in the NICU.

RDS is a multisystem disease that requires a multifaceted approach to improve outcomes. These strategies begin in the delivery room, extend to the NICU management and continue in the outpatient management of survivors. The Special Edition provides an update to the current thought regarding clinical and basic research that may be invoked to provide the best clinical care to our most fragile patients. Bringing treatment of RDS from laboratory to bedside [4,5] and beyond has made this an exciting project. We believe that pediatricians who care for neonates will find this series of review articles intriguing, even if you do not agree with all that is written. I hope that the pediatric residents rotating though our NICUs will find these articles a useful introduction to the management of premature babies with RDS. There is some obligatory redundancy in the various reviews, arising from the different perspectives of the individual authors, all practicing clinicians.

There are many controversies and uncertainties regarding optimal management of premature infants with RDS, beginning with choosing the best strategy of respiratory support in the delivery room. The next controversy surrounds the use of surfactant therapy, which surfactant, what dose, how many doses, and how and when it should be administered. Comparisons of available animal derived surfactant preparations is incomplete, but there appear to be benefits to a rapidly acting, animal-derived surfactant with a high concentrations that allows a large initial dose, $200 \mathrm{mg} / \mathrm{kg}$, twice the dose of other surfactant preparations [6-8]. This is concordant with the observation that two doses of surfactant are better than a single dose in the treatment of patients with severe respiratory distress syndrome $[9,10]$. Even with use of surfactant, variations in respiratory management of patients with RDS result in profoundly different rates of bronchopulmonary dysplasia [11-13]. A review of the multitude of mechanical ventilation strategies and the withering array of new terms to describe available ventilation strategies is presented. A review of the newer strategies of Non-Invasive Positive Pressure Ventilation is also presented, as it appears that mere placement of an endotracheal may increase the frequency of chronic lung disease [14]. The contribution of the cardiovascular system in the management of RDS is reviewed. The cardiovascular effects of RDS treatment represent a poorly studied clinical area. Regional hemodynamic responses to RDS and its treatment in premature infants may cause unanticipated changes in cerebral, PDA and intestinal blood flow. Surfactant type and volume and administration protocols as well as permissive hypercapnea may have profound hemodynamic effects [15-17]. The change in our views regarding management of a PDA in premature infants is now extremely controversial and is reviewed in detail. We may no longer need to treat most infants with PDAs and the treatment may, in fact be detrimental $[18,19]$. Clearly more clinical research is needed.

Management of extremely premature infants with chronic lung disease after discharge from the NICU is an even more controversial topic where the management strategies of the NICU and the outpatient pulmonologist may conflict. For example, while use of systemic corticosteroids clearly improves lung function, the therapeutic cost of neurotoxicity makes it an unacceptable routine therapy [20]. Nonetheless, steroid treatment for infants with severe RDS with evolving chronic lung disease and for certain outpatients, steroid management of chronic lung disease is sometimes indicated. Furthermore, infants with pulmonary hypertension and bronchopulmonary dysplasia represent a very high risk population of NICU graduates [21,22]. It is unclear whether continued supplemental oxygen therapy sufficient, or should other strategies the initiated.

We have not attempted to address the efficacy of adjunct therapies, e.g. Superoxide Dismutase (rhSOD) and Clara Cell Secretory protein (rhCC10) for the treatment of RDS and prevention of BPD [23-25]. These new drugs are currently not available for use in the United States and, while promising, do not have adequate supportive clinical trials data to recommend routine use. Clinical trials for rhCC10 are ongoing.

We hope that this series of reviews will inform and stimulate discussion amongst neonatologists and pediatricians who care for neonates and graduates of NICUs. In addition, since the World Health Organization has recently added surfactant to the list of essential medicines for developing countries, a timely review of current strategies utilized in the United States may be beneficial to pediatricians new to the management of RDS in premature babies.

\section{References}

1. Garite TJ, Kurtzman J, Maurel K, Clark R (2009) Obstetrix collaborative research network: impact of a 'rescue course' of antenatal corticosteroids: a multicenter randomized placebo-controlled trial. Am J Obstet Gynecol 200: 248.el-9.

2. Sweet DG, Carnielli V, Greisen G, Hallman M, Ozek E, et al. (2010) European consensus guidelines on the management of neonatal respiratory distress syndrome in preterm infants - 2010 update. Neonatology 97: 402-417.

*Corresponding author: Alan Fujii, Department of Pediatrics, Boston Medical Center, Boston University School of Medicine, One Boston Medical Center Place, Boston, MA 02118, USA, Tel: 617-414-5461; Fax: 617-414-7297; E-mail: alan.fujii@bmc.org

Received August 06, 2013; Accepted August 08, 2013; Published August 12 2013

Citation: Fujii AM (2013) Controversies in the Management of Respiratory Distress Syndrome in Premature Neonates. J Pulmon Resp Med S13: e001. doi:10.4172/2161-105X.S13-e001

Copyright: (c) 2013 Fujii AM. This is an open-access article distributed under the terms of the Creative Commons Attribution License, which permits unrestricted use, distribution, and reproduction in any medium, provided the original author and source are credited. 
Citation: Fujii AM (2013) Controversies in the Management of Respiratory Distress Syndrome in Premature Neonates. J Pulmon Resp Med S13: e001. doi:10.4172/2161-105X.S13-e001

Page 2 of 2

3. Aladangady N, McHugh S, Aitchison TC, Wardrop CA, Holland BM (2006) Infants' blood volume in a controlled trial of placental transfusion at preterm delivery. Pediatrics 117: 93-98.

4. AVERY ME, MEAD J (1959) Surface properties in relation to atelectasis and hyaline membrane disease. AMA J Dis Child 97: 517-523.

5. Long W, Corbet A, Cotton R, Courtney S, McGuiness G, et al. (1991) A controlled trial of synthetic surfactant in infants weighing $1250 \mathrm{~g}$ or more with respiratory distress syndrome. The American Exosurf Neonatal Study Group I, and the Canadian Exosurf Neonatal Study Group. N Engl J Med 325: 16961703.

6. Ramanathan R, Rasmussen MR, Gerstmann DR, Finer N, Sekar K, The North American Study Group (2004) A randomized, multicenter masked comparison trial of poractant alfa (Curosurf) versus beractant (Survanta) in the treatment of respiratory distress syndrome in premature infants. Am J Perinatol 21: 109-119.

7. Ramanathan R, Bhatia JJ, Sekar K, Ernst FR (2013) Mortality in preterm infants with respiratory distress syndrome treated with poractant alfa, calfactant or beractant: a retrospective study. J Perinatol 33: 119-125.

8. Singh N, Hawley KL, Viswanathan K (2011) Efficacy of porcine versus bovine surfactants for preterm newborns with respiratory distress syndrome: systematic review and meta-analysis. Pediatrics 128: e1588-1595.

9. Speer CP, Robertson B, Curstedt T, Halliday HL, Compagnone D, et al. (1992) Randomized European multicenter trial of surfactant replacement therapy for severe neonatal respiratory distress syndrome: single versus multiple doses of Curosurf. Pediatrics 89: 13-20.

10. Soll R, Ozek E (2009) Multiple versus single doses of exogenous surfactant for the prevention or treatment of neonatal respiratory distress syndrome. Cochrane Database Syst Rev : CD000141.

11. Avery ME, Tooley WH, Keller JB, Hurd SS, Bryan MH, et al. (1987) Is chronic lung disease in low birth weight infants preventable? A survey of eight centers. Pediatrics 79: 26-30.

12. Van Marter LJ, Pagano M, Allred EN, Leviton A, Kuban KC (1992) Rate of bronchopulmonary dysplasia as a function of neonatal intensive care practices. J Pediatr 120: 938-946.

13. Van Marter LJ, Allred EN, Pagano M, Sanocka U, Parad R, et al. (2000) Do clinical markers of barotrauma and oxygen toxicity explain interhospital variation in rates of chronic lung disease? The Neonatology Committee for the Developmental Network. Pediatrics 105: 1194-1201.

14. Kanmaz HG, Erdeve O, Canpolat FE, Mutlu B, Dilmen U (2013) Surfactant administration via thin catheter during spontaneous breathing: randomized controlled trial. Pediatrics 131: e502-509.

15. Kaiser JR, Gauss CH, Williams DK (2004) Surfactant administration acutely affects cerebral and systemic hemodynamics and gas exchange in very-lowbirth-weight infants. J Pediatr 144: 809-814.

16. Fujii AM, Bailey J, Doros G, Sampat K, Sikes NC, et al. (2009) Cerebra Blood Flow Responses to Beractant and Poractant Administration. Journal of Neonatal-Perinatal Medicine 2: 27-34

17. Kaiser JR, Gauss CH, Williams DK (2005) The effects of hypercapnia on cerebral autoregulation in ventilated very low birth weight infants. Pediatr Res 58: 931-935.

18. Benitz WE (2012) Patent ductus arteriosus: to treat or not to treat? Arch Dis Child Fetal Neonatal Ed 97: F80-82.

19. Adrouche-Amrani L, Green RS, Gluck KM, Lin J (2012) Failure of a repeat course of cyclooxygenase inhibitor to close a PDA is a risk factor for developing chronic lung disease in ELBW infants. BMC Pediatr 12: 10

20. American Academy of Pediatrics, Committee on Fetus and Newborn and Canadian Paediatric Society, Fetus and Newborn Committee (2002) Postnatal corticosteroids to treat or prevent chronic lung disease in preterm infants. Pediatrics 109: 330-338.

21. Khemani E, McElhinney DB, Rhein L, Andrade O, Lacro RV, et al (2007) Pulmonary artery hypertension in formerly premature infants with bronchopulmonary dysplasia: clinical features and outcomes in the surfactant era. Pediatrics 120: 1260-1269.

22. Kumar VH, Hutchison AA, Lakshminrusimha S, Morin FC 3rd, Wynn RJ, et al. (2007) Characteristics of pulmonary hypertension in preterm neonates. $J$ Perinatol 27: 214-219.

23. Davis JM, Parad RB, Michele T, Allred E, Price A, et al. (2003) Pulmonary outcome at 1 year corrected age in premature infants treated at birth with recombinant human CuZn superoxide dismutase. Pediatrics 111: 469-476.

24. Ramsay PL, DeMayo FJ, Hegemier SE, Wearden ME, Smith CV, et al. (2001) Clara cell secretory protein oxidation and expression in premature infants who develop bronchopulmonary dysplasia. Am J Respir Crit Care Med 164: 155161.

25. Levine CR, Gewolb IH, Allen K, Welch RW, Melby JM, et al. (2005) The safety, pharmacokinetics, and anti-inflammatory effects of intratracheal recombinant human Clara cell protein in premature infants with respiratory distress syndrome. Pediatr Res 58: 15-21.
This article was originally published in a special issue, Controversies in the Management of Respiratory Distress Syndrome in Premature Neonates handled by Editor(s). Dr. Alan Fujii, Boston University, USA 